\title{
EFEKTIVITAS PERANGKAP NYAMUK KASA APUNG SEBAGAI PERANGKAP NYAMUK AEDES AEGYPTI DI WILAYAH ENDEMIS DBD KOTA TANGERANG
}

\author{
*Cecep Dani Sucipto , *Kadar Kuswandi
}

\begin{abstract}
Abstrak
Kejadian Luar Biasa (KLB) penyakit DBD di awal tahun 2015 terjadi hampir merata di seluruh Indonesia, salah satu faktornya adalah lemahnya upaya pengendalian populasi nyamuk Aedes aegypti yang masih mengandalkan insektisida baik larvasida maupun imagosida sebagai pembunuh nyamuk Ae. aegypti. Pemakaian insektisida yang berlebihan dengan dosis yang kurang tepat berdampak pada resistensi pada nyamuk vektor. Metode pengendalian yang baik harus memenuhi kriteria efektiv, efesien dan ramah lingkungan, sehingga perlu ada inovasi teknologi pengendalian vektor DBD yang aplikatif dan teruji. Tujuan penelitian ini adalah untuk menguji efektivitas perangkap nyamuk kasa apung sebagai perangkap nyamuk Ae. aegypti di wilayah endemis DBD Kota Tangerang. Perangkap ini didesain sedemikian rupa sehingga nyamuk dewasa yang mau bertelur tetarik untuk meletakan telurnya di alat ini sehingga berfungsi sebagai tempat perindukan (breeding pleaces), perangkap di adopsi dari perangkap (ovitrap) terbuat dari kaleng susu yang di beri cat hitam serta di lengkapi kasa dan pelampung yang berfungsi sebagai perangkap nyamuk dewasa yang sudah menetas. Penelitian ini bersipat eksperimen yaitu mennguji perangkap kasa apung langsung di lokasi endemis DBD sebanyak seratus perangkap setiap lokasi endemis yang berjumlah tiga lokasi endemis yaitu Kecamatan Periuk, Cipondoh dan dan Jati Uwung. Hasil penelitian ini dianalisa dengan uji -T. Berdasarkan hasil penelitian jumlah nyamuk Aedes aegypti betina dewasa yang mati di perangkap kasa apung sebanyak 225 ekor dengan rata - rata setiap mosquito traf 15 ekor setiap perangkap, Jumlah nyamuk Aedes aegypti betina dewasa yang mati pada oiltraf sebanyak 198 ekor dengan rata -rata 13 ekor setiap perangkap dan Perangkap nyamuk kasa apung effektif sebagai perangkap di banding oiltraf. Adapun yang menjadi saran dari penelitian ini adalah kepada instansi terkait disarankan mencoba alternative pengendaliaan populasi nyamuk dengan perangkap kasa apung dan Perlu penelitian lanjut terutama penerapannya di lapangan dengan cakupan wilayah yang luas.
\end{abstract}

Kata Kunci: Efektivitas ,Perangkap Nyamuk Kasa Apung ,Nyamuk Aedes aegypti

*Poltekkes Kemenkes Banten 


\section{Latar Belakang}

Fenomena pergeseran kejadian luar biasa (KLB) DBD di Indonesia, sebelumnya pada tahun 1970-1990 KLB terjadi secara berkala 4-6 tahun telah mengalami pergeseran sejak tahun 2005 menjadi 3-4 tahun, bahkan di beberapa kota KLB terjadi dalam jangka waktu 1-2 tahun (Kusriastuti, 2005). Selama tahun 2008 jumlah penderita DBD di Banten mencapai 802 orang. Sedangkan pada tahun 2009 sampai bulan Juli kasus DBD mencapai 800 kasus dan 40 orang meninggal dunia atau telah mengalami out break.

Pada masa KLB dan dalam musim penularan penyakit DBD, penggunaan insektisida tidak dapat dihindarkan. Penggunaan insektisida untuk pengendalian vektor dalam skala luas secara terus menerus dalam jangka waktu cukup lama dan frekuensi tinggi dapat menimbulkan terjadinya penurunan kerentanan pada nyamuk sasaran (WHO, 1995; Georghiou \& Mellon, 1983). Hal ini terbukti adanya kecenderungan resistensi nyamuk terhadap insektisida di beberapa daerah di Indonesia, salah satu contohnya penelitian yang dilakukan di Kota Bandung terhadap jenis insektisida sipermetrin telah mengalami resistensi (Dindin, 2008).

Sejak tahun 1991 sampai dengan sekarang Dinas Kesehatan Kota Tangerang menggunakan malation dalam program pengendalian DBD. Mulai tahun 2003 sipermetrin digunakan sebagai insektida pendamping malation dengan alasan insektisida tersebut berbeda golongan, dimana malation termasuk golongan organofosfat sedangkan sipermetrin (Cynop) golongan piretroid.

Pemakaian insektisida yang berlebihan dengan dosis yang kurang tepat berdampak pada resistensi pada nyamuk vektor. Metode pengendalian yang baik harus memenuhi kriteria efektiv, efesien dan ramah lingkungan, sehingga perlu ada inovasi teknologi pengendalian vektor DBD yang aplikatif dan teruji. Salah satu teknik pengendalian populasi nyamuk adalah menggunakan perangkap nyamuk (mosquito trap), beberapa tipe yang sudah di gunakan adalah oil trap, letal steak trap dan light trap. Inovasi alat perangkap memerlukan kajian terus menerus dengan pengembangan berbagai metode perangkap

Berdasarkan uraian diatas, kami tertarik untuk mengetahui efektivitas perangkap nyamuk kasa apung sebagai perangkap jentik nyamuk Ae.aegpyti di daerah endemis tinggi DBD di Kota Tangerang. Perangkap ini didesain sedemikian rupa sehingga nyamuk dewasa yang mau bertelur tetarik untuk meletakan telurnya di alat ini sehingga berfungsi sebagai tempat perindukan (breeding pleaces), 
Metode Penelitian

Penelitian dilakukan secara eksperimen semu yaitu menguji efektivitas perangkap nyamuk kasa apung dalam membunuh nyamuk aedes aegypti di daerah endemis Kota Tangerang. Populasi penelitian adalah nyamuk Ae. aegypti di daerah endemis tinggi kota Tangerang. Penelitian ini dilaksanakan bulan Mei sampai september 2015, sedangkan lokasi penelitian di lakukan di Laboratorium Jurusan Analis Kesehatan Banten. Penelitian dilaksanakan dalam beberapa tahap kegiatan diantaranya: (1) pembuatan ovitrap, (2) pengambilan sampel nyamuk/larva dan telur Ae. aegypti di lokasi penelitian, (3) kolonisasi Ae. aegypti di laboratorium. Pelaksanaan penelitian dilakukan melalui memasang perangkap di ruang uji coba yang telah di kondisikan dengan luasan 63 m2.Jumlah perangkap masing-masing pengulangan sebanyak 15 buah. Pengecekan dilakukan setiap hari sampai hari ke 14, dimana satu siklus hidup Aedes aegypti dari mulai telur sampai dewasa selama kurang 10 sampai 14 hari. Pada hari ke 14 dilakukan pengecekan jumlah nyamuk dewasa yangt terperangkap dan dilakukan pencatan untuk selanjutnya di analisis tingkap efektifitas alat pernangkap. Hasil penelitian di analisis secara deskriptif dan di uji menggunakan uji statistik T -test.

\section{Hasil}

Penelitian dilakukan di kampus Analis Kesehatan Poltekkes Banten, pengujian skala laboratorium dengan membandingkan jumlah kematian nyamuk pada perangkap kasa apung dengan oil traf, jumlah perangkap yang di uji masingmasing 15 perangkap, masing-masing perangkap diuji 15 ekor jentik Ae.aegypti setelah satu minggu di observasi tingkat kematiannya pada masing - masing perangkap.

\section{Tabel}

Hasil uji eksperimen antara alat Perangkap Kasa apung dengan oil traf

\begin{tabular}{|c|c|c|}
\hline No & $\begin{array}{c}\text { Perangkap Kasa } \\
\text { Apung }\end{array}$ & Oil Traf \\
\hline 1 & 15 & 13 \\
\hline 2 & 15 & 12 \\
\hline 3 & 15 & 14 \\
\hline 4 & 15 & 13 \\
\hline 5 & 15 & 13 \\
\hline 6 & 15 & 15 \\
\hline 7 & 15 & 13 \\
\hline 8 & 15 & 14 \\
\hline 9 & 15 & 13 \\
\hline 10 & 15 & 14 \\
\hline 11 & 15 & 15 \\
\hline 12 & 15 & 12 \\
\hline 13 & 15 & 13 \\
\hline 14 & 15 & 13 \\
\hline 15 & 15 & 11 \\
\hline Jumlah & 225 & 198 \\
\hline Rata-rata & 15 & 13,2 \\
\hline
\end{tabular}

Tabel diatas menunjukkan jumlah nyamuk yang mati selama penelitian sebanyak 225 ekor pada mosquito traf kasa apung dan 198 ekor pada perangkap tipe oil 
traf, jumlah nyamuk yang mati terperangkap pada perangkap tipe jala apung lebih banyak yaitu rata 15 ekor per perangkap (100\%) di banding pada tipe oil traf dengan rata 13,2 ekor atau $88 \%$ tingkat kematiannya setelah perlakuan oiltraf.

\section{Pembahasan}

Hasil penelitian terhadap kematian nyamuk Ae.aegypti dengan menggunakan perangkap kasa apung mampu membunuh seluruhnya (100\%), perubahan dari stadium stadium tiga hingga keluar menjadi nyamuk dewasa sekitar 4 sampai 5 hari, posisi pupa saat nyamuk keluar pertama kalinya berada dipermukaan air sehingga nyamuk akan tertahan oleh kasa yang terapung, pada saat yang bersamaan sayap nyamuk kontak dengan air sehingga menghambat pergerakan nyamuk untuk mengepakkan sayapnya, akibat energi yang di keluarkan saat keluar dari pupa tersebut nyamuk mengalami kelelahan dan akhirnya mati.

Tingginya efektifitas kasa apung dalam membunuh nyamuk Ae.aegypti mencapai $100 \%$ diakibatkan berfungsinya secara maksimal jala apung yang memiliki diameter $0,75 \mathrm{~mm}$ tidak bisa di lewati nyamuk Ae.aegyti sesaat setelah menetas yang memiliki bentangan sayap sepanjang 5,0 $\mathrm{mm}$ dan pada saat bersamaan posisi sayap terendam air akibat tekanan jala apung sehingga menghambat pergerakan nyamuk Ae.aegypti.

Hasil penelitian pada kasa apung sejalan dengan hasil penelitian Suharno, dkk pada penelitian tutup kasa skrin yang dilakukan di Kota Pontianak dimana hasilnya efektif menghambat nyamuk yang keluar dari breeding pleaces berupa tempayan penyimpanan air masyarakat berupa tempayan penyimpan air hujan di Kota Pontianak. Sedangkan penelitian lainnya atas nama Cecep, dkk yang meneliti efektifitas mosquito trap dalam membunuh Ae. aegypti Jumlah nyamuk Aedes aegypti betina dewasa yang mati di mosquito traf sebanyak 4732 ekor dengan rata - rata setiap mosquito traf 6 ekor setiap hari.

Sedangkan pada oil traf tingkat kematian mencapai $88 \%$ dengan rata 13,2 ekor yang terperangkap dan satu sampai empat ekor setiap perangkap lolos dari jebakan oiltraf, hal ini dimungkinkan akibat tidak meratanya tutupan minyak menutupi permukaan perangkap, sehingga sessat setelah menetas sebagian kecil bisa keluar dari jebakan, sedangkan yang lainnya terjebak akibat sayap atau bagian tubuh lainnnya kontak dengan minyak.

Minyak memiliki kemampuan untuk membunuh, seperti dijelaskan oleh Sriasi dalam buku parasitologi kesehatan 
menyatakan minyak kontak pada serangga masuk melalui eksoskelet dengan perantaraan tarsus ( jari kaki ) pada saat hinggap sehingga bisa membunuh nyamuk sasaran.

Hasil penelitian ini bisa ditindak lanjuti penelitian lanjutan skala lapangan untuk aplikasi pada program pengendalian kepadatan populasi nyamuk Aedes aegypti sehingga akan menekan kasus DBD atau antisipasi terjad.inya kejadian luar biasa (KLB). Kelebihan pengendalian dengan menggunakan perangkap selain sederhana juga lebih murah jika di banding dengan pengendalian secara kimiawi, cara pemeliharaannya alat perangkap kasa apung dengan mengecek volume air setiap minggu, penempatannnya bisa ditempatkan indoor amaupun outdoor, sekitar tempat-tempat umum seperti masjid, sekolah, pasar, terminal, pelabuhan,dll. Kelebihan pengendalian dengan perangkap bisa menghindari resiko resistensi pada serangga sasaran serta efek toksisitas pada hewan bukan sasaran dan manusia. Dibanding perangkap jenis yang sama seperti stiek ovitraf yang menggunakan insektisida pada perangkapnya bisa menimbulkan resiko resistensi.

Dari hasil penelitian dan pembahasan tersebut di atas terdapat beberapa kelemahan penelitian ini diantaranya tidak bisa memantau secara seksama dari setiapnya jam, sehingga kurang mendetail proses yang terjadi selama penelitian.

\section{Simpulan}

Berdasarkan hasil penelitian terhadap kemampun mosquito traf dalam membunuh nyamuk Aedes aegypti betina dewasa di daerah rawan DHF di Kota Tangerang dapat disimpulkan sebagai berikut :

1. Jumlah nyamuk Aedes aegypti betina dewasa yang mati di perangkap kasa apung sebanyak 225 ekor dengan rata - rata setiap mosquito traf 15 ekor setiap perangkap

2. Jumlah nyamuk Aedes aegypti betina dewasa yang mati pada oiltraf sebanyak 198 ekor dengan rata -rata 13 ekor setiap perangkap

3. Perangkap nyamuk kasa apung effektif sebagai perangkap di banding oiltraf.

\section{Daftar Pustaka}

1. Basset, W.H, Clay's Hand Book OF Environmental Healht, Chapman \& Hall, Oxpord, London,1995

2. Departemen Kesehatan RI, Petunjuk Pengamatan Demam Berdarah Dengue, Jakarta, 1997.

3. Iskandar, dkk, Pemberantasan Serangga Dan Binatang Pengganggu, Pusdinakes, Jakarta, 1992 
4. Sriasi,dkk, Parasitologi Kesehatan, FK UI, Jakarta, 1988

5. Candra Budiman. 2007. Pengantar Kesehatan Lingkungan. Penerbit Buku Kedokteran. EGC.

6. Chareonviriyaphap., Rongnoparut P., Chantarumporn P.J., Bang Michael. 2003. Biochemical detection of pyretroid resistance mechanisms in Anopheles minimus in Thailand. Journal of Vector Ecology. 28: 108-116.

7. Christopher S.R. 1960. Aedes aegypti, the yellow fever mosquito. Cambridge Univ Press, London. 307-33.

8. Darwin Akhid. 2008. Status Kerentanan An. Balabacensis dan An. Aconitus Terhadap Insektisida Piretroid Sintetik di Kabupaten Magelang Provinsi Jawa Tengah. Tesis. UGM. Yogyakarta

9. Djojosumarto Panut. 2008. Pestisida \& Aplikasinya. PT Agromedia Pustaka. Jakarta

10. Depkes, RI. 2004. Perilaku dan Siklus Hidup Nyamuk Aedes aegypti Sangat Penting Diketahui Dalam Melakukan Kegiatan Pemberantasan Sarang Nyamuk Termasuk Pemantauan Jentik Secara Berkala. Bulletin Harian. Jakarta.

11. Depkes, RI. 2005. Kasus Demam Berdarah Dengue (DBD) di Indonesia. Bulletin Harian. Jakarta.

12. Depkes, RI. 2005. Pemberantasan Nyamuk Penular Demam Berdarah
Dengue. Dirjen Pengendalian Penyakit dan Penyehatan Lingkungan. Jakarta.

13. Ffrench-Constant R.H. \& Bonning. B.C. 1989. Rapid mictotitre plate test distinguishes insecticide resistant acetylcholinesterase genotypes in mosquitos Anopheles albomanus, An. Negerrimus and Culex pipiens 3. 9-16

14. Gandahusada., Ilahude S., Pribadi W. 2006. Parasitologi Kedokteran. Ed.III. Balai Penerbit FKUI. Jakarta.

15. Georghiou, G.P. and R.B. Mellon. 1983. Pesticide Resistence in Time and Space. In: Pest Resistence to Pesticides (Eds. G.P. Georghiou \& T. Saito). Plenum Press, New York. P. 1-46.

16. Georghiou, G.P. 1986. The Magnitude of Resistance Problem. Pesticide Resistance. National Academy Press. Washington

17. Hamington L.C., Edman J.D and Scott T.W. 2000. Why do Aedes aegypti (Diptera: Culicidae) feed preferentially on human blood. J. Med. Entomol $38: 411-422$

18. Hemingway J and C. Smith. 1986a. Field and laboratory Detection of the Altered Acetylcholine esterase Resistance genes Which Confer Organophosphate and Carbamat Resistance in Mosquitoes (Diptera: Culicidae). Bulletin Entomological Research. 76: 559-565 
19. Hemingway J. and H. Ransom. 2000. Insecticide resistance in insect vectors of human disease. Annu. Rev. Entomol. 45: 371-391

20. Hardiyanto, S. 1996. Infeksi Subklinis Mycobacterium leprae dan hubungannya dengan Faktor-faktor Risiko di Indonesia. Kajian Seroepidemiologik dan Imunogenetik. Desertasi. UGM. Yogyakarta

21. Herath, P. 1997. Insecticides Resistance in Disease Vectors and its Practical Implication. WHO. Geneva.

22. Karunaratne SHP and Hemingway J. 2001. Malathion Resistance and Prevalence of the Malathion Carboxylesterase Mecanism in Population of Mosquito Vector of Disease in Sri Langka. Bulletin of the World Health Organization. 2001; 79(11): 1060 $-1064$

23. Kusbaryanto, Mardihusodo SJ, Tjokrosonto S. 2002. Deteksi resistensi larva Culex quinquefasciatus say terhadap malathion dengan teknik bercak kertas saring di Sleman, Daerah Istimewa Yogyakarta, J.Ked.Yarsi 2002; 10(1): 14 $-25$

24. Lee, H.L. 1990. A Rapad and Simple Biochemical Method for the Detection of insecticida Resistance Due to Elevate Esterase Activity in Culex quinquefasciatus. Tropical Biomedicine. 7: 21-26.

25. Lee, H.L. 1991. Esterase Activity and Temephos Susceptibility in Aedes aegypti (L) Larvae. Mosquito Borne Disease Bull. 8: 91-94.

26. Seng C.M. and Jute N. 1986. Dengue and dengue hemorrhagic fever outbreak in Lawas Districs, Sarawak, East Malaysia. Med. J. Malaysia. 41:310-319.

27. Sigit, S.H. dan Hadi, U.K. 2006. Hama Pemukiman Indonesia (Pengenalan, Biologi dan Pengendalian). Unit Kajian Pengendalian Hama Pemukiman. Fakultas Kedokteran Hewan. Institut Pertanian Bogor.

28. Small, G. 1998. Genetical background of insecticide resistance, Paper Molecular Entomology Workshop, Center for Tropical Medicine Gadjah Mada University. Yogyakarta.

29. Smith C.G.E. 1956. The History of dengue in tropical Asia and its probable relationship to the mosquito Aedes aegypti. J. Trop. Med. Hyg. 59:3-8.

30. Sucipto, Cecep Dani, 2011, Vektor Penyakit Tropis, Gossyen Publishing, Yogyakarta.

31. Sudijono. 1983. Malathion. Ditjen P3M Depkes RI. Jakarta

32. Sungkar, S. 2005. Bionomk Aedes aegypti, vector Demam Berdarah Dengue. 
Majalah Kesehatan Indonesia 55 (4): 384389.

33. Suroso T. 2000. Development of DHF control policy in Indonesia from 1968 to 2000. Depkes RI. Jakarta.

34. Sutaryo. 2004. Dengue. Medika, Fakultas Kedokteran, Universitas Gadjah Mada Yogyakarta. 